\title{
Do carry trades in the foreign exchange markets influence stock prices?
}

\author{
Yutaka Kurihara \\ Dept. of Economics, Aichi University, Nagoya, Japan
}

Email address:

kurihara@vega.aichi-u.ac.jp

\section{To cite this article:}

Yutaka Kurihara. Do Carry Trades in the Foreign Exchange Markets Influence Stock Prices? International Journal of Business and Economics Research. Vol. 2, No. 4, 2013, pp. 84-90. doi: 10.11648/j.ijber.20130204.11

\begin{abstract}
Carry trades have been shown to lead to significant changes in foreign exchange markets by producing shocks to interest rate differentials. This study uses fundamentals and the chartist model for the foreign exchange markets in which market participants can choose to become carry traders. It shows that carry trades play an important role in determining foreign exchange rates. Carry trades can influence exchange rates (Japanese yen and Euro against the US dollar). Also, the relationship between carry trades and three stock prices are examined empirically. As the rate of carry trades increases, stock prices in Japan and Germany rise. However, during the period of the Lehman shock, the increasing rate of carry trades may have caused a decline in Japanese stock prices, and huge amounts of money were reported to have been invested in carry trades at that time using interest rate differentials. Massive capital for carry trades seem to have been flown into foreign currencies (ex, FX) rather than stocks.
\end{abstract}

Keywords: Carry Trade, Chartist, Exchange Rate, Fundamental, Stock

\section{Introduction}

Recently, near zero short-term interest rates in the United States and Japan have launched huge capital flows from carry trades (see, for example, [1]). It has been said that carry trades have influenced exchange rates in the world. Since 2007, exchange rates have moved and fluctuated largely all over the world and many economists have stated that carry trades caused the turmoil. Although the foreign exchange market has been analyzed using two isolated approaches (i.e., fundamental analysis and chartist [technical] analysis [2][3]), carry trades should be considered. Since at least the middle of the 2000s, carry trades cannot be ignored in determining exchange rates.

Some academic studies about carry trades have appeared since the Lehman shock [4]. Just before that, the interest differential among countries had expanded and exchange rate movements and volatility had increased greatly. Interest rate differentials in some developed countries have been impacted by various financial policies (United States and Japan vs. Euro countries). Certain circumstances may be said to cause carry trades. Reference [5] showed that demand and confidential shocks rather than financial policy and supply shocks generate unexpected interest rate differentials and gains. Reference [6] showed that high interest rate currencies are negatively related to market volatilities. Reference [7] investigated the performance of carry trades with non-deliverable contracts and found that the contracts are associated with higher Sharpe ratios than deliverable contracts. Reference [8] found a close link between risk reversals and speculative future positions for the Japanese yen. Carry trades have started to be examined in the research; however, the number of the studies is not large in spite of the importance.

Carry traders are strongly related to interest rate parity. Covered and uncovered interest rate parity theory has long been employed in the real economy to make profits and have been cited repeatedly in academic papers. Reference [9] suggested that the expected change in the exchange rate equals the spread in interest rates. Reference [10] surveyed many studies and showed evidence of a forward premium puzzle in the foreign exchange markets. Reference [11] showed that the puzzle in the foreign exchange markets is caused by a combination of nonrational expectations and risk premium puzzle. Reference [12] proofed that the puzzle exists in developed countries. References [13] and [14] showed that non-stationary time series are the reason for the puzzle. Reference [15] showed that the puzzle is a short-term phenomenon. References [16], [17], and [18] showed that the puzzle could be explained by 
heterogeneous agents. Most studies have found that covered interest rate parity holds; on the other hand, they have showed that the uncovered interest parity does not hold. There should be some room for agents in the markets to use the failure of uncovered interest rate parity. The typical case is carry trades.

Reference [16] proofed there are two types of traders in the foreign exchange markets: fundamentalists and chartists. This study showed that fundamentalists expect the exchange rate to revert to its fundamental value and chartists tend to extrapolate the trend for the recent period. References [19] and [20] showed that heterogeneous market participants are active in the yen/dollar market, whereas the stabilizing movement of the fundamentalists declines in times of misalignment. Recently, in the field of behavioral economics/finance, [21] showed that market participants first choose the optimal behavioral portfolio theory, overlook covariances among markets, and allocate funds across markets according to a rule to attain mean-variance efficiency or to minimize the loss. Reference [22] employed a stochastic chartist-fundamental model and showed that a stochastic delay-differential equation incurred market-like stock price dynamics that reflect the effects of time delay.

Carry trades in the foreign exchange markets are basically performed with the failure of uncovered interest parity. Carry trade means that one borrows in a country with relatively low interest rates and converts to countries with high interest rates. However, carry trade does not result in excess returns because the interest rate differential should be compensated for by the change in the foreign exchange rates. Carry trades in the foreign exchange markets are profitable because of the failure of uncovered interest rate parity [23][24][25][26][27].

In sum, carry traders influence exchange rate determination particularly via the failure of uncovered interest rate parity [28]. Also, the use of fundamental and chartist models is useful in examining exchange rate determination; on the other hand, carry trades should be considered and included in the real economy or in the model at the same time. However, the two ideas have been discussed separately. Only [29] analyzed this issue; however, the effects on stock prices considering the fundamental-chartist model and carry trades have not been discussed. The relationship between carry trades in foreign exchange markets and stock markets has not been analyzed despite its importance.

This study is structured as follows. Section 2 shows a theoretical model based on fundamental and chartist models. Carry trades are incorporated in the model. Market participants can choose among three selections: fundamental, chartist, and carry trades. In section 3 , empirical analyses are performed based on the model explained in section 2. The relationship between carry trades and stock markets is examined empirically. Finally, this study ends with a brief summary.

\section{A Carry Trades Model}

\subsection{Three-Agents Model}

First, the foreign exchange rate is given by the uncovered interest rate parity model:

$$
\text { st }+1=s t(1+i t) /\left(1+i^{*} t\right)
$$

where $\mathrm{s}$ is the spot exchange rate. $\mathrm{i}$ and $\mathrm{i}^{*}$ are domestic interest rate and foreign interest rate. $\mathrm{t}$ means time. This equation is used for carry traders and is explained later. For the case of covered interest rate parity theory, the forward/future exchange rate is determined instead of the spot exchange rate expectation.

Fundamental analysis essentially focuses on the overall state of the economy. Fundamentalists expect the exchange rate to converge toward the uncovered interest parity's fundamental rate. This can be expressed as follow:

$$
\mathrm{Ef,t}(\Delta \mathrm{st}+1)=\alpha(\mathrm{s} * \mathrm{t}-\mathrm{st})
$$

where Ef,t $(\Delta s t+1)$ is the expected change in the exchange rate for fundamentalists. E denotes expectation's operator. $f$ means fundamentals. $\alpha$ is the speed at which the fundamentalists believe the exchange rate returns to its fundamental value. $\mathrm{s}^{*}$ denotes the fundamental spot exchange rate.

Second, chartist (technical) analysis predicts the movements of exchange rates by examining the past (historical) data for the market. This analysis is used not only for foreign exchange markets but also for example, for stock markets in reality. Chartists expect the exchange rate to follow the same pattern as it did in the previous period. The expectations of the chartists for exchange rates are given by:

$$
\operatorname{Ec}, t(\Delta s t+1)=\beta \Delta s t
$$

where Ec,t $(\Delta s t+1)$ is the change in the exchange rate expected by the chartists and c means chartists. $\beta$ is the degree of extrapolation of past changes.

Third, as per [24][26][27], carry traders are included along with fundamentals and chartists in this model. They expect the exchange rate to move in opposition to the uncovered interest parity relationship. If the interest rate differential is positive (e.g., $\mathrm{i}>\mathrm{i}^{*}$ ) (negative), the theory of uncovered interest parity predicts a depreciation (appreciation) of the domestic currency. In this case, carry traders can yield profits by borrowing in the low interest rate currency, converting it to the high interest rate currency, and investing it. Their expectations result in extra demand for the high interest rate currency and hence an appreciation, as carry traders use the failure of uncovered interest parity. This can be expressed as follows:

$$
\text { Ect, } t(\Delta s t+1)=-\gamma(s * t-s t)
$$

where Ect,t $(\Delta s t+1)$ is the change in the exchange rate expressed by carry traders. $\gamma$ means the degree to which 
carry traders expect the interest rate differentials to influence the exchange rate. ct denotes carry trade. Carry traders can obtain profits by borrowing the low interest rate currency, changing it to the high interest rate currency, and investing it; however, the adopted investments (including stocks) are examined in this paper.

\subsection{A Switching Model}

It is assumed that agents expressed as in equations (2), (3), and (4) in markets can switch among three different exchange rate expectations. Fundamentalists use the following:

$$
w f, t=\pi f, t /(\pi f, t+\pi c, t+\pi c t, t)
$$

where w means the weight. f, c, and ct mean fundamentals, chartists, and carry trades. $t$ denotes time. $\pi$ means profit. Contrary to some existing studies (e.g., [26][27]), risks (e.g., volatility) are omitted as they cannot be evaluated accurately. There also are differences in evaluation that should be taken into account by agents, periods, currencies, and so on.

Also, in the case of chartists, the profit is calculated as follows:

$$
\mathrm{wc}, \mathrm{t}=\pi \mathrm{c}, \mathrm{t} /(\pi \mathrm{f}, \mathrm{t}+\pi \mathrm{c}, \mathrm{t}+\pi \mathrm{ct}, \mathrm{t})
$$

Finally, the case of carry traders is expressed as follows:

$$
\text { wct, } \mathrm{t}=\pi \mathrm{ct}, \mathrm{t} /(\pi \mathrm{f}, \mathrm{t}+\pi \mathrm{c}, \mathrm{t}+\pi \mathrm{ct}, \mathrm{t})
$$

The profit of fundamentalists, chartists, and carry traders is as follows:

$$
\pi \mathrm{i}, \mathrm{t}=[\mathrm{st}(1+\mathrm{i} * \mathrm{t})-\mathrm{st}-1(1+\mathrm{i})] \operatorname{sign}[\mathrm{Et}-1(\mathrm{st})(1+\mathrm{i} * \mathrm{t})-\mathrm{st}-1
$$

where $\mathrm{i}=\mathrm{f}, \mathrm{c}$, and $\mathrm{ct}$, and $\operatorname{sign}(\mathrm{x})=1($ if $\mathrm{x}>0), 0($ if $\mathrm{x}=0)$, and -1 (if $\mathrm{x}<-1$ ).

It is assumed that market participants can freely select three types of transactions and switch from one to another without any costs. However, it also is assumed that these market participants must select among three transactions [28]. Exchange rate expectation is determined by the weighted average of the expectations of the three groups [29][30]. They can be calculated using [2][3][5][6][7] and [8].

Finally, it is assumed that the increase (decrease) of the weight of carry trades influences stock prices in the same (opposite) direction using the failure of uncovered interest parity. Carry traders can obtain capital at low interest rates and invest it in stock markets. However, this process depends on the situations in the markets. The markets here are not limited to foreign exchange (currency) markets. Exchange rates, interest rates, and stock prices and their movements (i.e., volatility) and their expectations influence the choice of investments; in this case, stocks or other financial instruments (currency is a typical case) are candidates for investment.

\section{Empirical Analysis}

\subsection{Exchange Rates and Carry Traders}

In this section, empirical analyses are performed based on the model explained in section 2. The sample period is from 2005 to 2013 (the end of July). Moreover, it is divided into smaller periods, which are explained later. The data are daily. The fundamental exchange rates $s^{*}$ are derived using the Hodrick-Prescott filter. This method is used often because it separates the cyclical component of a time series from the original raw data. This method can obtain a smoothed time series, which is more sensitive to long-term than to short-term fluctuations. Exchange rates at the end of each day are used. Interest rates are interbank rates (one month). All the data are from the Nikkei Telecom (Japanese newspaper company) database.

First, the values of $\alpha, \beta$, and $\gamma$ should be determined. It is assumed that Et $(\Delta s t+1)=s t+1$. The estimated results of (2) through (4) are as follows.

$<$ Japanese yen/US dollar $>$

$$
\begin{aligned}
& \text { Ef,t }(\Delta \mathrm{st}+1)=0.049(\mathrm{~s} * \mathrm{t}-\mathrm{st}) \\
& \text { t value: } 2.198 \quad \text { adj.R2: } 0.024 \quad \text { D. W. } 2.001 \\
& \mathrm{Ec}, \mathrm{t}(\Delta \mathrm{st}+1)=0.091 \Delta \mathrm{st} \\
& \begin{array}{lll}
t \text { value: } 1.970 & \text { adj.R2: } 0.007 & \text { D. W. } 1.990
\end{array} \\
& \text { Ect, } \mathrm{t}(\Delta \mathrm{st}+1)=-2.082(\mathrm{~s} * \mathrm{t}-\mathrm{st}) \\
& \begin{array}{lll}
t \text { value: }-2.082 \quad \text { adj.R2: } 0.009 & \text { D. W. } 2.055
\end{array} \\
& <\text { Japanese yen/Euro }> \\
& \text { Ef,t }(\Delta \mathrm{st}+1)=0.096(\mathrm{~s} * \mathrm{t}-\mathrm{st}) \\
& \begin{array}{lll}
\mathrm{t} \text { value: } 4.418 \quad \text { adj.R2: } 0.010 & \text { D. W. } 2.000
\end{array} \\
& \mathrm{Ec}, \mathrm{t}(\Delta \mathrm{st}+1)=0.130 \Delta \mathrm{st} \\
& \text { t value: } 4.022 \quad \text { adj.R2: } 0.017 \\
& \text { Ect,t }(\Delta \mathrm{st}+1)=-0.098(\mathrm{~s} * \mathrm{t}-\mathrm{st}) \\
& \text { t value: }-4.419 \quad \text { adj.R2: } 0.010
\end{aligned}
$$

For most cases, the results are as expected, including the coefficient (positive/negative). Next, the weight, wf, wc, and wct are calculated. According to these results, the expected exchange rates are calculated for each day. Table 1 shows the results for estimated one and real data.

Table 1. Estimated exchange rates and real exchange rates (2005-2013: end of July)

\begin{tabular}{lllll}
\hline & US Dollar & \multicolumn{3}{l}{ Euro } \\
\hline & Estimated & Real & Estimated & Real \\
Average & 98.425 & 98.423 & 131.723 & 131.719 \\
Medium & 97.760 & 97.760 & 132.290 & 132.280 \\
Std. Dev. & 14.581 & 14.581 & 20.287 & 20.286 \\
Skewness & -1.391 & -1.391 & -1.077 & -1.077 \\
Kurtusis & 0.042 & 0.042 & 0.108 & 0.109 \\
\hline
\end{tabular}

The results are pretty good (see, for example, [31]). The model, including fundamentals, chartists, and carry trades, explains exchange rates in reality.

The weight for carry trades for all transactions is as 
shown in Table 2. The results show that the carry trades influence foreign exchange markets in general. The figure is almost one-third, which is comparatively high. Carry trades play important roles in determining exchange rates. Carry trades should not be ignored, at least on recent examination of exchange rate determinations. Also, it should be noted that carry trades influenced exchange rates more during the Lehman shock period (2007-2008). Market participants might exploit profits by using carry trades in the foreign exchange markets.

Table 2. Weight of carry trades in the foreign exchange markets

\begin{tabular}{lllll}
\hline $\begin{array}{l}\text { Sample } \\
\text { Period }\end{array}$ & $\mathbf{2 0 0 5 - 2 0 1 3}$ & & $\mathbf{2 0 0 7 - 2 0 0 8}$ & \\
\hline Currency & US Dollar & Euro & US Dollar & Euro \\
Average & 0.338 & 0.287 & 0.348 & 0.334 \\
Medium & 0.335 & 0.285 & 0.349 & 0.334 \\
Std. Dev. & 0.017 & 0.047 & 0.004 & 0.004 \\
Skewness & 7.157 & 21.610 & 8.041 & 21.220 \\
Kurtusis & 153.881 & 466.991 & 119.419 & 457.801 \\
\hline
\end{tabular}

\subsection{Stock Prices and Carry Traders}

The other purpose of this study is to examine the relationship between carry trades and stock prices. There is a possibility that capital used for carry trades has been invested into other markets (i.e., stock markets). However, there also is some possibility that investment flows into currencies or currency-related financial instruments rather than stocks. The relation should be analyzed empirically. There is some possibility of differences for time periods or currencies. The estimated equation is as follows:

stock price $=c+\alpha$ carry trades weight $+\beta$ exchange rate (9)

whether or not the increase (decrease) in weight of carry trades promotes rises in stock prices can be directly examined using equation (9). It is expected that increased weight of carry trades cause stock prices to rise if the capital used for the carry trades was invested in stock markets [31][32][33]. However, there is a possibility that the capital used for carry trades flows into currencies or currency-related financial instruments. Also, depreciation (appreciation) of the yen against the US dollar and Euro would increase exports and raise Japanese stock prices. The Japanese economy and industries depend much on exports. Increased exports usually promote stock prices.

The empirical method is generalized method of moments (GMM) instead of ordinary least squares (OLS), which is a robust estimator in that, unlike maximum likelihood estimation, GMM does not require information about the exact distribution of the disturbances. The GMM estimators are known to be efficient and asymptotically normal relative to other estimators that do not use any extra information in addition to that contained in the moment conditions. Hansen's J statistics test is performed. This test checks whether or not the model's moment matches the data.

The sample periods are: (1) from 2005 to 2013 (overall sample period), (2) from 2005 to 2006, (3) from 2007 to 2008, (4) from 2009 to 2012, and (5) from 2013 to the end of July, 2013. During period (2), Japanese interest rates were almost zero as the result of the introduction of the quantitative easing policy from 2001 to 2006 . From 2007 to 2008, period (3), the Lehman shock occurred and hit not only the world economy but also the US, European, and Japanese economies. For period (4), the United States also started to introduce quantitative easing. U.S. and Japanese interest rates compared to EU rates. Finally, for period (5), the Bank of Japan (Japanese central bank) decided to introduce quantitative and qualitative monetary easing. This move was designed to double the monetary base and the amounts of outstanding of Japanese bonds and so on in two years to overcome deflation and promote economic growth. Interest rates in Japan have been quite low since the beginning of the 2000s. This policy has resulted in confirmation of low interest rates. For stock prices, Nikkei Stock Average (Japan), NY Dow Jones (US), and DAX (Germany) are used. All data are daily average prices. The data are daily. The results of regression (9) are shown in Tables $3 a$ and $3 b$. For the cases of the United States and Germany, only the cases of the whole sample period are reported as the other periods have similar results.

Table 3a. Effect of carry trades on Japanese stock prices

\begin{tabular}{|c|c|c|c|c|c|}
\hline & 2005-2013 & 2005-2006 & 2007-2008 & 2009-2012 & 2013- \\
\hline $\mathbf{C}$ & $\begin{array}{l}-23324.46 \\
(-17.250)\end{array}$ & $\begin{array}{l}-16349.04 \\
(-5.615)\end{array}$ & $\begin{array}{l}-18179.19 \\
(-16.674)\end{array}$ & $\begin{array}{l}-4772.685 \\
(-6.538)\end{array}$ & $\begin{array}{l}6657.790 \\
(12.585)\end{array}$ \\
\hline Chartist weight & $\begin{array}{l}5930.223 \\
(1.662)\end{array}$ & $\begin{array}{l}33083.51 \\
(4.303)\end{array}$ & $\begin{array}{l}1048.168 \\
(0.550)\end{array}$ & $\begin{array}{l}-4002.417 \\
(-1.994)\end{array}$ & $\begin{array}{l}90.469 \\
(0.070)\end{array}$ \\
\hline Exchange rate & $\begin{array}{l}325.287 \\
(62.791)\end{array}$ & $\begin{array}{l}365.032 \\
(33.691)\end{array}$ & $\begin{array}{l}325.753 \\
(35.593)\end{array}$ & $\begin{array}{l}183.838 \\
(83.710)\end{array}$ & $\begin{array}{l}32.650 \\
(8.624)\end{array}$ \\
\hline Adj.R2 & 0.895 & 0.718 & 0.905 & 0.784 & 0.072 \\
\hline J-test & 6.230 & 6.145 & 8.267 & 8.892 & 3.243 \\
\hline Durbin-Watson & 0.056 & 0.130 & 0.347 & 0.018 & 0.028 \\
\hline
\end{tabular}

Note. The parentheses in the table indicate t-values. ***,**, and * denote significance at 1, 5, and $10 \%$. 
Table 3b. Effect of carry trades on US and Germany (EU) stock prices

\begin{tabular}{l|ll}
\hline & US & Germany \\
C & 11583.31 & 10891.147 \\
& $(12.528)$ & $(43.996)$ \\
Chartist weight & -1401.529 & 460.746 \\
& $(-0.502)$ & $(2.521)$ \\
Exchange rate & - & -42.412 \\
Adj.R2 & & $(-20.105)$ \\
J-test & -0.000 & 0.301 \\
Durbin-Watson & 0.252 & 3.751 \\
\hline
\end{tabular}

Note. The parentheses in the table indicate t-values. ${ }^{* *}, * *$, and * denote significance at 1,5 , and $10 \%$.
Moreover, shocks are examined using the impulse response function. The impulse response describes the reaction of the system as a function of other independent variables that parameterizes the dynamic behavior of the model. The variables used for estimation are carry trades weight, US stock price, German stock price, and Japanese stock. The results are shown in Fig. 1.

Response to Cholesky One S.D. Innovations \pm 2 S.E.
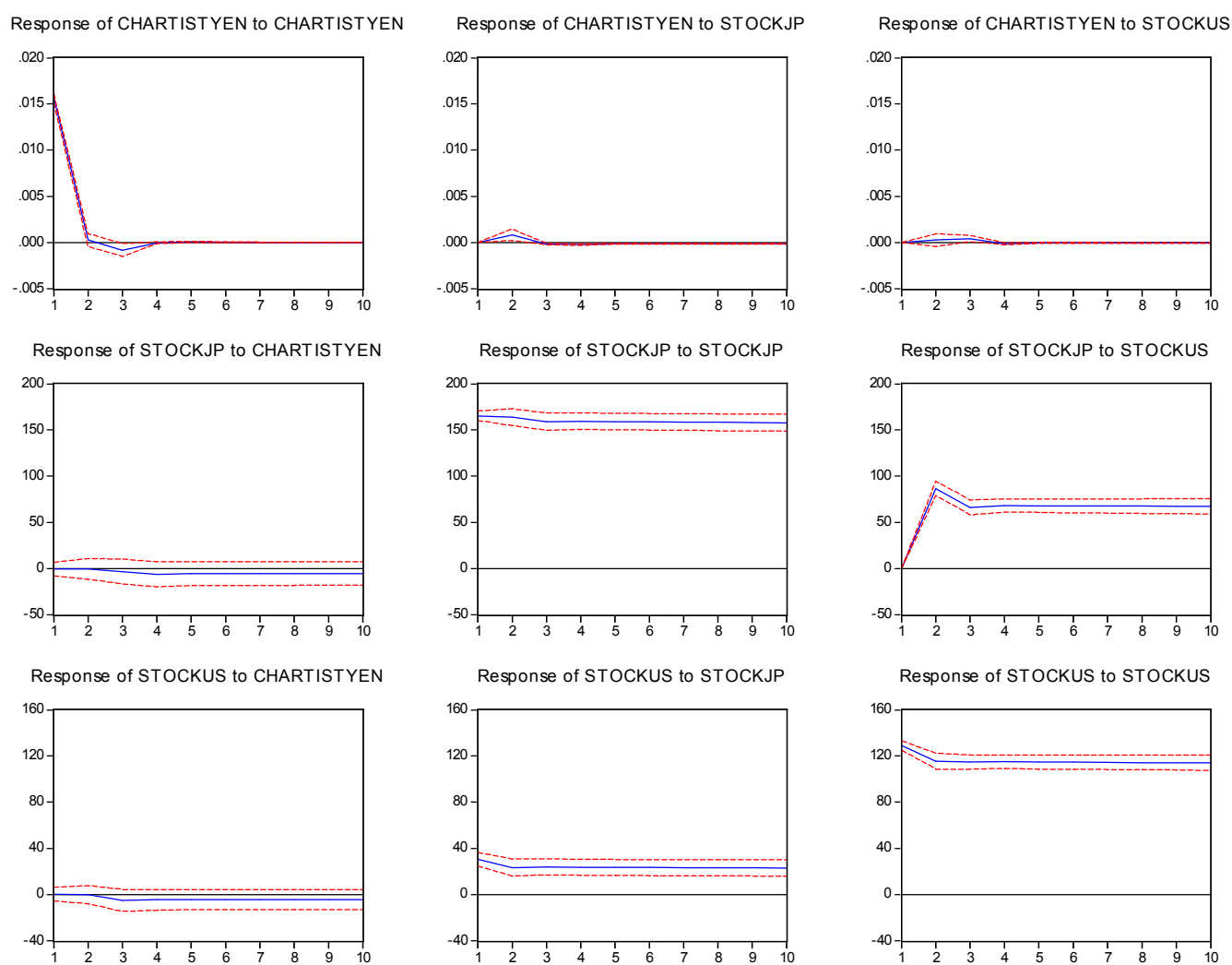

Figure 1. Impulse response function to the weight of chartist

The results shown in Tables $3 \mathrm{a}$ and $3 \mathrm{~b}$ and Fig. 1 show that increasing weight of carry trades influence Japanese stock prices positively; however, Japanese stock prices declined during the period of the Lehman shock.

Surely, it is difficult to evaluate how and to what extent carry trades affected stock prices at that time; however, the Lehman shock was so large on the real economy that carry trades themselves did not influence stock prices very much or carry traders might have avoided stock investment strongly. Market participants as a whole, had decreased to invest stocks.

The effects of carry trades on US and EU stock prices are different. US stock prices declined and German (EU) ones rose as the ratio of carry trades increased. However, the case of the United States is not significant. Carry traders may have invested in Japanese and Germany stock markets expecting to yield profits. For the case of the United States, massive capital for carry trades seems to be invested in currencies (i.e., FX) rather than stocks.

The relationship between stock prices and exchange rates is as expected. Depreciation (appreciation) of the yen promotes rises in stock prices in Japan (coefficient is positive), and appreciation (depreciation) of the Euro decreases (increases) stock prices in Germany (coefficient is negative). 


\section{Conclusion}

This study proofed that carry trades are part of the explanation of foreign exchange rate puzzles. Carry trades have been considered to have led to large changes and fluctuations in the foreign exchange markets via shocks to interest rates differentials. This study employed a model for the foreign exchange markets in which market participants choose carry trade models along with fundamental and chartist models and showed that carry trades play important roles in determining foreign exchange rates. Carry trades can influence exchange rates (Japanese yen against the euro and the US dollar). Also, the relationship between carry trades and stock prices were examined. As the rate of carry trades increases, stock prices in Japan and Germany rise. However, during the period of the Lehman shock (2007-2008), the increasing rate caused the decline in Japanese stock prices, and huge amounts of money were reportedly invested in carry trades. Massive capital for carry trades were expected to be invested in currencies (i.e., FX) rather than stocks.

Carry trades have started to receive some interest among researchers. These trades surely have played some part in financial markets. Much more study is need in this field. In particular, the relationship among macroeconomic variables should be examined more. The availability of daily or shorter time-span data may enable other empirical studies.

\section{Acknowledgements}

This work was supported by JSPS KAKENHI Grant Number 23243048.

\section{References}

[1] R. McKinnon, "Carry trades, interest differentials, and international monetary reform," Journal of Policy Modeling, vol. 34, no. 4, pp. 549-567, 2012.

[2] M. AbuHamad, M. Mohd, and J. Salim, "Event-driven business intelligence approach for real-time integration of technical and fundamental analysis in Forex market," Journal of Computer Science, vol. 9, no. 4, pp. 488-499, 2013.

[3] Y. Kurihara, "Exchange rate determination: Which is appropriate, chartist model or fundamental model?" Journal of Applied Finance and Banking, vol. 3, no. 3, pp. 187-198, 2013.

[4] T. P. Nguyen, "Causes and consequences of financial corruption: A conceptual inquiry," International Journal of Economics, Finance and Management Sciences, vol. 1, no. 2, pp. 115-118, 2013.

[5] A. Anzuini and F. Fornari, "Macroecnomic determinants of carry trade activity," Review of International Economics, vol. 20, no. 3, pp. $468-488,2012$.

[6] L. Menkhoff, L. Sarno, M. Schmeling, and A. Schrimpf, "Carry trades and global foreign exchange volatility," The Journal of Finance, vol. 67, no. 2, pp. 681-718, 2012.
[7] A. Doukas and H. Zhang, "The performance of NDF carry traders," Journal of International Money and Finance, vol. 36, no. 1, pp. 172-190, 2013.

[8] M. Hutchison and V. Sushko, "Impact of macro-economic surprises on carry trade activity," Journal of Banking and Finance, vol. 37, no. 4, pp. 1133-1147, 2013.

[9] E. F. Fama, "Forward and spot exchange rates," Journal of Monetary Economics, vol. 13, no. 3, pp. 319-338, 1984.

[10] K. A. Froot, "Short rates and expected asset returns," NBER Working Paper, 3247, 1990.

[11] M. Cavaglia, W. F. C. Verschoor, and C. C. P. Wolff, "On the biasedness forward foreign exchange rates: Irrationality or risk premia," Journal of Business, vol. 67, no. 3, pp. 321-343, 1994.

[12] R. Bansal and M. Dahlquist, "The forward premium puzzle: different tales from developed and emerging economies," Journal of International Economies, vol. 31, no. 1, pp. 115-144, 1999

[13] C. Engle, "The forward discount anomaly and the risk premium: a survey of recnt evidence," Journal of Empirical Finance, vol. 3, no, 1, pp. 123-192, 1996.

[14] R. Roll and S. Yan, "An explanation of the forward premium puzzle," European Financial Management, vol. 6, no. 1, pp. $121-148,2000$.

[15] M. D. Chinn and G. Meredith, "Monetary policy and long-horizon uncovered interest parity," IMF Staff Papers, vol. 51, no. 3, pp. 409-430, 2004.

[16] J. A. Frankel and K. A. Froot, "Chartists, fundamentalists, and trading in the foreign exchange markets," American Economics Review, vol. 80, no. 1, pp. 181-185, 1990.

[17] M. Obstfeld and K. Rogoff, "The six major puzzles in international macroeconomics: Is there a common cause?", NBER Macroeconomics Annual, vol. 15, 1996

[18] L. Sarno, "Viewpoint: Towards a solution to the puzzles in exchange rate economics: Where do we stand?" Canadian Journal of Economics, vol. 38, no. 3, pp. 673-708, 2005.

[19] A. M. Taylor and M. P. Taylor, "The purchasing power parity debate," Journal of Economics Perspective, vol. 18, no. 4, pp. $135-158,2004$

[20] C. W. Kao and Y. J. Wan, "Heterogeneous behaviours and the effectiveness of central bank intervention in the yen/dollar exchange market," Applied Financial Economics, vol. 22, no. 12, pp. 967-975, 2012.

[21] C. Jiang, Y. Ma and Y. An, "International portfolio selection with exchange rate risk: A behavioral portfolio theory perspective," Journal of Banking and Finance, vol. 37, no. 2, pp. 648-659, 2013.

[22] G. Dibeh and H. M. Harmanani, "A stochastic chartists model with time delays," Computational Economics, vol. 40, no. 2, pp. 105-113, 2012.

[23] C. Burnside, M. Eichenbaum, I. Kleshchelski, and S. Rebelo, "The returns currency speculation," NBER Working Paper, 12489, 2006.

[24] C. Burnside, M. Eichenbaum, and S. Rebelo, "The returns currency speculation in emerging markets," American 
Economic Review, vol. 97, no. 2, pp. 333-338, 2007.

[25] Z. Darvas, "Leveraged carry trade portfolios," Journal of Banking and Finance, vol. 32, no. 6, pp. 944-957, 2008.

[26] A. Chakraborty and G. W. Evans, "Can perpetual learning explain the forward premium puzzle?" Journal of Monetary Economics, vol. 55, no. 3, pp. 477-490, 2008.

[27] P. De Grauwe and M. Grimaldi, "Heterogeneity of agents, transaction costs and the exchange rate," Journal of Economic Dynamics and Control, vol. 29, no. 4, pp. 691-719, 2005.

[28] R. Spronk, W. F. C. Verschoor, and R. C. J. Zwinkels, "Carry trade and foreign exchange rate puzzle," European Economic Review, vol. 60, no. 1, pp. 17-31, 2013 .

[29] R. Sangeetha and J. Mathew, "A study on technical efficiency of public sector banks in India," International Journal of
Business and Economics Research, vol. 2, no. 2, pp. 15-21, 2013.

[30] W. Yue-Fang and M. H. Cao, "Short-run and long-run performance of IPOs: Evidence from Taiwan stock market," Journal of Finance and Accounting, vol. 1, no. 2, pp. 32-40, 2013.

[31] T. Serpil and M. Balıbey, "The relationships among interest rate, exchange rate and stock price: A BEKK - MGARCH approach," International Journal of Economics, Finance and Management Sciences, vol. 1, no. 3, pp. 166-174, 2013.

[32] G. Agrawal and A. Srivastava, "A study of exchange rates movement and stock market volatility," International Journal of Business and Management, vol. 5, no. 2, pp. 1-12, 2010.

[33] J. E. Gagnon and A. P. Chaboud, "What can the data tell us about carry trades in Japanese Yen?" International Finance Discussion Papers, 899. 